\title{
Anonimiteit en pseudonimiteit van Bybelse geskrifte
}

\author{
Herman Lombard
}

\section{Abstract \\ Anonamity and pseudonymity of biblical writings}

Since ancient times authors presented their writing to the public under pseudonyms. Subsequently, authors also wrote anonomously. The literary phenomenon of pseudonymity creates the most substantial problems among literary critics, since all cultures and authors' conventions emphatically reject plagiarism and forgeries. An assessment of this literary technique should be conducted with reference to the motives and objectives behind the utilization of this technique.

\section{PROBLEEMSTELLING}

In die bestudering van die literatuurwetenskap kry 'n navorser onder andere te doen met die verskynsels van 'anonimiteit' en 'pseudonimiteit'. Hierdie terme het te make met die outeursvraag en gevolglik ook met die kritiese bevraagtekening van die egtheid van dokumente.

Hierdie vrae oor outeur en egtheid van geskrifte word nie slegs ter wille van die interessantheid en/of die teoretiese akademiese belang van hierdie sake as sodanig gevra nie. Inteendeel, hierdie vrae dra gewig in die verstaan, uitleg en interpretasie van die dokumente. Dit is die geval omdat die vrae verband hou met en implikasies inhou vir die datering, agtergrond van die geskrif, Wirkungsgeschichte van die teks, redaksiegeskiedenis van die tradisie(s) wat ter sake is, die oogmerke en literêre tegnieke van die outeur, die status van die geskrif in die gemeenskap ensovoorts.

In 'n omvattende literatuurwetenskaplike ondersoek na Bybelse geskrifte het die verskynsels van anonimiteit en veral pseudonimiteit, benewens hierdie besondere relevansie vir die kritiese inleidingswetenskap, ook implikasies vir basiese aspekte van die kanonvraagstuk. Dit is in die mate só dat hierdie verskynsels en die implikasies daarvan dikwels in die brandpunt van studies oor die ontstaansgeskiedenisse van die kanons van die verskillende kerke staan. Vir hierdie rede skenk alle goeie handboeke oor inleiding tot die Nuwe Testament, 
en oor algemene kanoniek en kommentare op afsonderlike Bybelboeke, aandag hieraan.

In die konteks van religieuse literatuur kry ons dus te make met 'n bepaalde genuanseerde vorm van die probleme rondom anonimiteit en pseudonimiteit. Letterkundiges, literêre kritici en teoloë se vrae lê op twee vlakke, naamlik histories-kritiese ondersoeke èn teologies-etiese besinning. Daar word gevra hoe die verskynsels literêr verstaan, teologies-eties beoordeel en psigologies begryp word? (kyk o a Torm 1932: 19vv; Meyer 1936: 262vv). In religieuse literatuur is hierdie vraag van fundamentele belang, aangesien dit deurdring tot enersyds ' $n$ ondersoek na die verhouding tussen die outeur, sy boodskap, sy teologiesetiese waardes en kulturele milieu van sy lesers, en andersyds die outeursaanspraak waarmee hy sy boodskap aanbied. 'n Outeur in hierdie geledere moet ' $n$ beslissing maak ten opsigte van die vraag of sekulêre literêre tegnieke en konvensies dienlik en toelaatbaar is as voertuie vir sy spesifieke boodskap (kyk o a Balz 1969: 403vv).

Hierdie vraag bring die kritiese ondersoeker vanselfspekend by die vraag na die motiewe en oogmerke wat funksioneer wanneer 'n outeur anoniem of pseudoniem skryf (kyk o a Metzger 1972: 5-12).

In hierdie verband moet daar, metodologies beskou, 'n suiwer historiese perspektief nagehou word. Die volgende metodologiese oorwegings moet funksioneer:

\section{1}

Daar moet ondersoek ingestel word of dit ten tyde van die ontstaan van die bepaalde religieuse geskrifte 'n algemene literêre konvensie was om anoniem of pseudoniem te skrywe (kyk o a Goodspeed 1937: 169; Aland 1961: 39; Speyer 1966: 95, 111v; Metzger 1972: 5vv; Fischer 1977: 76vv).

\section{2}

Alternatiewelik kon die Bybelse outeurs vir bepaalde teologiese, godsdienstige en retoriese redes hierdie konvensie vir hulself geskep het, soos wat die vroeg-Christelike outeurs die literêre genre 'evangelie' geskep het. 


\section{3}

Die kritiese ondersoeker moet die saak uitmaak in hoeverre en op watter voorwaardes die gebruikmaking van hierdie literêre tegniek vir die vroeë kerk en vir verskillende Christelike gemeenskappe aanvaarbaar was. Die aanvaarbaarheid, al dan nie, van geïdentifiseerde anonieme en pseudonieme geskrifte word onder andere gedemonstreer deur die lesing van sulke geskrifte by die eredienste (in die eerste tot die tweede eeu) èn deur die insluiting van sulke geskrifte in die kanons van die Oosterse, Westerse en Siriese kerke.

\section{4}

Die finale metodologiese vraag is dus of godsdienstige geskrifte wat gedurende die eerste tot vierde eeu as anonieme en/of pseudonieme geskrifte geïdentifiseer was, vir die vroeë kerk aanvaarbaar en gesaghebbend sou wees of nie. Hier geld die beginsel dat die tweede-eeuse en derde-eeuse norme, reaksies en beskouings oor outeurskap en egtheid, dit wil sê húlle opvatting oor wie die outeurs was, moet geld en nie die twintigste-eeuse beskouings oor outeurskap en literêre tegnieke nie.

Dit kom daarop neer dat die moderne evaluering van hierdie verskynsels en ons resultate van histories-kritiese ondersoeke na outeurskap en egtheid (veral sedert die Aufklärung en daarna) géén relevansie het vir ' $n$ ondersoek na die voorkoms en evaluering van die verskynsels by die vroeë kerk nie.

Die tersaaklike vraag is en kan alleen wees: Hoe sou die vroeë kerk op grond van hulle beskouings oor outeurskap en hierdie tegnieke gereageer het, indien hulle sou weet (wat ons in die twintigste eeu beweer om te weet!) dat die boeke onder die name van Moses, baie profete, evangelies, sommige Pauliniese briewe, ander onder die name van Johannes, Jakobus, Judas en Petrus verkeerdelik (pseudoniem) as geskrifte van hoogaangeskrewe figure aangedui was?

As die vroeë kerke ten onregte (volgens ons insig) die tradisies oor outeurskap geskep of van die 'apostoliese vaders' (sedert Klemens Romanus) en van die apologete geërf het, waarom het hulle dit gedoen?

Het hulle daardeur 'n eiesoortige literêre konvensie ten opsigte van outeurskap geskep waarin die klem nie soseer op die persoon van die outeur val nie, maar op die outentieke inhoud van sy geskrif?

Of het 'n ander opvatting ten opsigte van die skeppers en skepping van religieuse literatuur gefunksioneer, naamlik dié van die geestelike 
eenheid en solidariteit tussen apostels en hulle leerlinge (navolgers)? (kyk o a Wrede 1900: 75vv; Harrison 1921: 12v; Harrington 1962: 23v; Guthrie 1962: 43-45; Speyer 1966: 110v; Balz 1969: 408v; Brox 1973: 16-26; Zmijewski 1979: 162vv). Of moet uiteindelik met N Brox (1973: $16 \mathrm{vv}$ ) saamgestem word dat Nuwe-Testamentiese pseudepigrafiese geskrifte sonder meer vervalsings en bedrog is?

\section{5}

Die beskikbare primêre literatuur uit die eerste drie eeue sal noukeurig en krities ondersoek moet word om bogenoemde vrae binne die historiese en teologiese verwysingsraamwerk van die vroeë kerke te beantwoord.

\section{6}

Metodologies beskou, moet die insigte en resultate van die moderne histories-kritiese ondersoeke egter aangewend word om vas te stel of óns opvatting oor die beskouings binne die geledere van die vroeë kerk klop met die ware toedrag van sake destyds.

\section{BETEKENIS VAN TERME}

Die terme 'anonimiteit' en 'pseudonimiteit' het eerstens en hoofsaaklik met die outeurskap van geskrifte te make.

Verreweg die meeste van die geskrifte van die Bybel is anonieme geskrifte. Die outeursaanduidings kom uit afleidings en/of sekondêre en tersiêre fases van die tradisiegeskiedenisse van die tekste.

Daar is verskeie redes waarom outeurs hulle name verswyg of doelbewus weerhou. Dit kan wees omdat die aandag op die eintlike outeur, naamlik God, gode, orakel, gevestig word. Soms is dit ook vanweë 'n gangbare literêre konvensie of skrywersmode waardeur aangetoon word hoe bekend die outeur (sy denke en styl) is sodat dit oorbodig of selfs ' $n$ belediging is om sy naam te verstrek.

Die term 'pseudonimiteit' dui daarop dat 'n geskrif van 'n 'skynnaam' of 'vals naam' voorsien is. Die aanduiding van outeurskap is dus in die vorm van 'n skuilnaam of impersonasie.

Hierdie verskynsel lewer nie probleme op as die skuilnaam op 'n 
fiktiewe persoon of simbool dui nie. Sodra pseudonimiteit egter verwys na 'n bepaalde persoonlikheid wie se naam gebruik word, word dit uiters problematies. So 'n geskrif word dan 'n pseudepigrafon genoem.

Daar is ook gevalle bekend waar iemand of ' $n$ groep ' $n$ pseudoniem aan ' $n$ anonieme geskrif verbind het. Andersyds is ' $n$ bekende naam aan 'n geskrif toegevoeg waarvan die inhoud, gedagtegang en styl sterk aan ' $n$ bekende outeur herinner.

Die literêre tegnieke van anonimiteit en pseudonimiteit is welbekend in die geskiedenis van patriargale, klassieke en Hellenistiese letterkunde tot in die moderne tyd (kyk o a Haeffner 1934: 8-15; Sint 1960: 25vv; Aland 1961: 30-45).

Die omstandighede van, aanleiding tot en motiewe agter die gebruik van hierdie tegnieke verskil van tyd tot tyd en van groep tot groep. Die navorsing om ' $n$ omvattende beeld en korrekte insig hierin te verkry en dit te beoordeel, het al ' $n$ lang pad geloop.

Die is dus noodsaaklik om nou 'n kort oorsig oor die geskiedenis van navorsing en die stand van ondersoek te gee.

\section{KORT OORSIG VAN DIE NAVORSINGSGESKIEDENIS}

Die etiese en teologiese besinning oor en historiese ondersoek na die literêre tegnieke onder bespreking lê op verskillende vlakke en word deur verskeie faktore na vore geroep.

In die algemeen kan met stelligheid gekonstateer word dat grondige en kritiese besinning hieroor dateer vanaf die tydstip dat geleerdes bewus geword het van growwe misbruike wat met die gebruik van hierdie tegnieke gepaard gegaan het. Dit is naamlik die tydstip toe doelbewuste vervalsings, plagiaat en skending van outeursreg aan die kaak gestel is.

Vanaf hierdie tydstip moes en het literatore norme vir die toepassing van egtheidskritiek van geskrifte vasgestel. Dit alles het grondige besinning geverg.

Die vraag wat vanselfsprekend na vore getree het, was of pseudonimiteit legitiem en aanvaarbaar is in die sin dat dit onderskei kan word van doelbewuste literêre vervalsings. In 'n diepgaande ondersoek in hierdie verband het BM Metzger (1972: 3-24) hierdie vraag in die geskiedenis van literatuur nagevors. Hy maak inderdaad 'n sterk saak uit vir die onderskeiding tussen legitieme pseudepigrafie en literêre vervalsings. Laasgenoemde ontstaan, wanneer 'n geskrif pseudoniem 
verskyn met die opsetlike doel om die lesers ten opsigte van outeurskap te bedrieg en onder 'n wanindruk te plaas. Indien hierdie doelbewuste opset ontbreek en ander aanvaarbare oogmerke geld, het ons waarskynlik met 'n aanvaarbare literêre tegniek te make. Dit kan dan 'n outeurskonvensie genoem word.

\subsection{Vroeë geskiedenis van besinning oor pseudonimiteit}

Pogings en prosedures om tussen pseudepigrafa en opsetlike vervalsings te onderskei en om egtheidskritiek toe te pas, dateer reeds uit die tyd van die Griekse dokters Hippokrates (vierde eeu v C) en Galen (tweede eeu v C).

Daar was vervalsings onder hulle name en redaksionele interpolasies by hulle werke het geweldige afmetings aangeneem. Daarom het Galen self 'n pamflet uitgegee, getiteld Oor sy eie boeke (kyk o a Marquart \& Helmreich 1891: 91vv; Bröcker 1881: 415vv).

Uit die vierde eeu v $C$ is ook vervalsings deur Anaksimenes van Lampsakis onder die naam van sy tydgenoot, die historikus Teopompus van Chios (378-300 v C), bekend. Die vervalser het in sy boek Tripolitikus (of Trikaranos) lasterlike dinge oor die stede Athene, Tebes en Sparta geskryf (kyk Pausanias se History of Greece 6.18.2vv). Flavius Josefus (Contra Apionem 1.221v) maak hiervan melding en veroordeel die tegniek by Griekse historici deur te sê dat hierdie boek sekerlik nie (ou gar de) deur Teopompus geskryf was nie. Hy ontmasker ook die fiktiewe aard van die aanklagte en beswaddering (tas diabolas kai tas loidorias, hais kegreutai tines).

'n Ander voorbeeld van geïdentifiseerde vervalsings is die traktate wat die neo-Pitagoreërs aan hulle leermeester toegeskryf het, eeue na sy dood (kyk o a Deubner (ed) 1937: 108, 4-7; Thesleff 1961: 24, 3)!

Oor hiedie doelbewuste vervalsings skryf Eusebius van Sesarea (260-339 n C) in sy Historia Ecclesiastica (HE) 9.5.1 dat só ' $n$ geskrif in die vierde eeu verskyn het, getiteld Handelinge van Pilatus. Die eintlike outeur was die afvallige Christen Teoteknus. Hierdie outeur word beskryf met terme soos deinos kai ghoēs (geslepe bedrieër), ponēros anēr (bose man) en iemand wat dia spoudes pepoiemenos panta te epi diabolé kai katëghoria (enige uitvindsel aanwend om te laster). Daar is ook 148 vervalste Griekse briewe in die tweede eeu v $C$ op die naam van Falaris (sesde $v$ C) in omloop gestuur. Bentley (1874: $5 \mathrm{vv}$ ) bestempel dit as 'worthless forgery'.

Hierby kan ook nog die pseudepigrafon, die Aristeasbrief, korrespon- 
densie tussen koning Abgar en Jesus en 14 vervalste briewe uit die korrespondensie tussen Paulus en Seneka genoem word. Oor laasgenoemde het Hiëronimus (Epistolae 153) geskryf.

Ten einde doelbewuste literêre vervalsings van outentieke geskrifte en memoirs aangaande bekende outeurs te onderskei, het grammatici en literatore reeds in antieke tye toetse ontwerp en aangelê. So is Griekse outeurs reeds in die sewende eeu v $C$ teen plagiaat beskerm en het hulle dit ten sterkste besweer (Speyer 1965/66: 88vv). Voorbeelde van hierdie verwerping en beswering vind ons by Vetruvius (eerste eeue v C) in sy Praefectus (7.4v) en by Suetonius in sy Vita Horati waarin hy Horatius se eie elegieë en prosa van vervalsings onderskei het (kyk o a Peter 1911; Stemplinger 1912; Hosius 1913: 176-93).

Gevorderde egtheidskritiek is reeds deur Herodotos (Historiae 7.6.3), Ion van Chios, Aristoteles, Porfurius (ten opsigte van die werke van Pitagoras), Galen ensovoorts toegepas (kyk o a Balz 1969: 408vv). In die derde eeu $\mathrm{n} C$ het Dionisius van Aleksandrië kriteria vir egtheid op grond van woordeskat, styl en inhoud ontwerp en op die Openbaring van Johannes toegepas.

Dit is opgevolg deur Hiëronimus (De Viris illustribus - vierde eeu) se vyf kriteria om vervalsings en valse outeursaanduidings (pseudonieme) te identifiseer (kyk Hulley 1944: 104-9).

In hierdie werke is sterk terme van afwysing en karakterisering van sulke geskrifte gebruik, soos paragarattein $=$ adulterare (= vervals, verduistering van munte), plattein = configere (= fabrisering van ' $n$ storie, verdigsel), rhadioughein = falsare (= bedrieg, vervals), pseudos anaferesthai eis tina $=$ supponere (leuen aanbring by iets).

Uit hierdie seleksie uit ' $n$ massa van getuienis is dit duidelik dat kritici sedert die vroeë fase van die literatuurgeskiedenis vervalsings geidentifiseer en ten sterkste daarteen gereageer het.

Hierteenoor is daar ruimte vir 'n literêre konvensie, soos byvoorbeeld pseudonimiteit. Deur middel van hierdie konvensie kon leerlinge in en navolgers van bepaalde tradisies en denkwêrelde in verband en medewerking met beroemde en gesaghebbende outeurs uit die verlede tree.

\subsection{Moderne besinning oor pseudonimiteit en anonimiteit}

In die vorige paragraaf is reeds verwys na studies veral uit die laaste kwart van die negentiende eeu waarin die verloop en toedrag van sake sedert die sewende eeu v C ondersoek is. Hierdie studies omvat mo- 
derne besinning oor die besinning gedurende antieke en klassieke tye oor die literêre tegnieke onder bespreking.

Die verdere verloop van navorsing en meningsvorming oor hierdie aspek wat ook die Bybelwetenskap raak, verdien nou die aandag.

Die navorsing het ' $n$ belangrike momentum gekry met die bydrae van W Wrede (1900: 75-85) oor die probleme rakende literêre pseudonimiteit in die Nuwe Testament. Benewens die bogenoemde studies (kyk punt 3.1) wat die voorlopers van Wrede se ondersoek was, is daar ook nog ander uit die laaste deel van die negentiende eeu. 'n Oorsig oor hierdie ondersoeke bied insig in die hooflyne van belangstelling en besinning.

Die resultate van ondersoeke bring die volgende na vore:

\subsubsection{Edmund Chambers}

In 1891 verskyn Edmund K Chambers se History and motives of literary forgeries waarin 'n goeie oorsig oor literêre vervalsings gedurende die antieke, Middeleeuse en moderne tye gegee word. Vanweë die omvang en waarde van hierdie studie is dit in 1970 herdruk (New York: Burt Franklin).

\subsubsection{Alfred Gudeman}

In 1894 verskyn twee publikasies van Alfred Gudeman waarin literêre vervalsings in Griekse en Romeinse literatuur behandel word. Die onderwerp is van soveel belang dat die publikasies in ' $n$ feesbundel vir Henry Drisler en in die amptelike orgaan van die Amerikaanse Filologiese Werkgemeenskap verskyn het.

\subsubsection{0 - Wêreldoorlog I}

Gedurende hierdie tyd is die werk van Wrede en Gudeman voortgesit. Tot en met Wêreldoorlog I het James A Farrar in 1907 en FF Abbott in 1908 'n legio van literêre vervalsings in na-Middeleeuse, modern-Westerse, Midde-Oosterse en Latynse literatuur geidentifiseer. Laasgenoemde studie het aan die lig gebring dat $7,7 \%$ van die 144044 Latynse inskripsies wat in die Corpus Inscriptionum Latinarium gelys is, vervals is. 


\subsubsection{Wêreldoorlog I-II}

TF Trout (1918-20: 209vv) het redelik suksesvol aangetoon hoeveel en hoedanig vervalsings gedurende die Middeleeue geskep is. Die rede is waarskynlik dat hierdie tegniek in hierdie tyd nouliks as 'n misdaad beskou is. Die geskiedenis van die skepping van literêre vervalsings is deur H Willrich (1924: 5vv, passim) na die Hellenistiese tyd teruggevoer en hy het aangetoon hoedat oorkondes van die Hellenisties-Joodse tradisies vervals is.

'n Ander terrein van hierdie literêre aktiwiteit is verken deur EJ Goodspeed (1931, uitgebrei en herdruk in onderskeidelik 1956 en 1968). Dit is naamlik die verskynsel dat moderne pseudepigrafiese evangelies ontstaan het. Dit het op die voetspoor van apokriewe evangelies uit die tweede tot vierde eeue plaasgevind. Hierdie geskrifte is 'strange new gospels', 'modern apocrypha' en 'biblical hoaxes' genoem.

By die skepping van religieuse pseudepigrafa is daar sterk psigologiese en persoonlikheidsfaktore by die outeur werksaam. Dit het, volgens F Torm (1932) en A Meyer (1936: 262-79), 'n groot rol by pseudepigrafa van die oer-Christendom gespeel.

'n Variante vorm van literêre vervalsings is deur DL Page (1934) uitgewys toe hy aangetoon het hoedat die interpretasies van akteurs as interpolasies tot die tekste van Griekse dramas toegevoeg is. Dit is die duidelikste aantoonbaar by Euripides se Ifigeneia in Aulis.

Hierna het G Bardy (1936: 5-23) uitgewys dat pseudepigrafa in die vorm van literêre vervalsings inderdaad ook in die geledere van die vroeë Christendom voorgekom het. Dit het hewige konflikte binne die religieuse gemeenskappe tot gevolg gehad vanweë die sterk afwysende houding oor sulke opsetlike praktyke (kyk ook o a Meyer 1936: 270vv).

\subsubsection{Na Wêreldoorlog II tot hede}

In 1945 het EH Clift aangetoon hoedat beroemde name van klassieke tye valslik aan geskrifte van die veel latere tyd van die Romeinse Republiek, veral die tyd van keiser Augustus, gekoppel is.

'n Reuse-bydrae is in 1951 deur A Taylor en FJ Mosher gelewer toe hulle die navorsingsresultate in die vorm van 'n bibliografiese geskiedenis van anonieme en pseudonieme geskrifte opgestel het. Dit is opgevolg deur die Italianer Alessandro Ronconi (1956: 15-37) wat 'n algemene inleiding op pseudepigrafiese literatuur geskryf het.

'n Nuwe veld is ontgin toe LC Hector (1959) die aspek van die paleografie by pseudepigrafie betrek het. Hy pas geldige kritiek op be- 
staande teorieë toe en toon die verband tussen paleografie en literêre vervalsings gedurende die Middeleeue aan.

In dieselfde jaar (1959) lewer K Aland 'n voordrag voor die NuweTestamentiese klub van die Universiteit van Chicago. Hy lê die vrug van sy studie oor anonimiteit en pseudonimiteit in die Christelike literatuur van die eerste drie eeue voor. Hy onderskei Christelike pseudepigrafie en anonimiteit van Christelike geskrifte van ander vorme van hierdie verskynsels. Die onderskeiding is volgens Aland (1961: 39-49) geldig en noodsaaklik op grond van die feit van die werksaamheid van die Heilige Gees as die auctor primarius van hierdie geskrifte.

Sedert die sestigerjare van ons eeu kom één algemene tendens in navorsing weer sterk na vore. Dit is om die ondersoeke nogtans toe te spits op die verskynsels van anonimiteit en pseudonimiteit in antieke en klassieke tye, met besondere toespitsing op die voorkoms hiervan in religieuse literatuur.

Agtereenvolgens is aspekte behandel soos die verband tussen religieuse pseudepigrafie èn literêre vervalsings (Speyer 1965/66: 88-125), literêre en teologiese probleme verbonde aan hierdie verskynsels in die vroeë Christendom (Balz 1969: 401-36), die onderskeiding tussen literêre vervalsings en religieuse pseudepigrafie en die motiewe agter hierdie gebruike (Sint 1960; Metzger 1972: 3-24), pseudepigrafie in die Nuwe Testament self (Fischer 1977: 76-81), valse outeursaanduidings en die poging om Christelike pseudepigrafie te verklaar (Brox 1973, 1975, 1978, 1979).

Verder het J Zmijewski (1979: 161-72) pseudepigrafie in die Nuwe Testament en in die apostoliese oorlewering na aanleiding van 2 Petrus 1: 13 en 3: 1 ondersoek en die standpunt van dubbele pseudonimiteit van outeur en lesers in die Pastorale Briewe beredeneer (1980: 97-118). Beide hierdie komponente kom volgens hom uit die geledere van leerlinge van Paulus. Volgens hom is die doel van die skepping van sulke Christelike pseudepigrafa nie om doelbewus te vervals of te bedrieg of literêre fiksie te skep nie. Die outeur wou slegs die geloofsopset en suiwere leer van die apostel waarborg, sy tradisie suiwer weergee en by die bepaalde behoeftes van die geïmpliseerde gehoor aanpas.

\section{SAMEVATTING EN INTERPRETASIE}

Die voorafgaande oorsig en uiteensetting van die resultate van die navorsing het uitgewys dat en hoedat geleerdes bepaalde tendense en gebruike in die skep van literatuur geïdentifiseer het. 
By wyse van samevatting kan die volgende nou gestel word:

\section{1}

Die gebruik om anoniem en pseudoniem te skrywe, is in die Westerse en Midde-Oosterse literatuurgeskiedenis sedert die klassieke tye bekend. Dit kom veelvuldiglik voor in sekulêre èn religieuse literatuur.

\section{2}

Die motiewe en oogmerke by outeurs om anoniem of pseudoniem te skrywe, is velerlei van aard en word deur die gangbare konvensies en denkwêreld bepaal. Metzger (1972: 5vv) identifiseer agt sulke motiewe en beweegredes by outeurs van antieke, klassieke en moderne tye. Hieronder val:

- Die motief van winsbejag, naamlik om boeke te skrywe en onder groot name te verkoop, soos die vervalsings onder dokter Galen se naam vir die nuwe biblioteek van Pergamus (eerste helfte van die tweede eeu $n \mathrm{C}$ ).

- Nabootsing en vervalsing uit pure kwaadwilligheid, of uit respek of liefde en beskeidenheid teenoor ' $n$ beroemde leermeester of groot figuur. Voorbeelde is die geskrifte van die neo-Pitagoreërs onder Pitagoras se naam en 'n brief van Timoteus in die jaar $440 \mathrm{n} \mathrm{C}$.

- Die komposisie van dramatis personae in die proses van die verering van groot Attiese redenaars, soos Antifon, Isokrates, Demostenes en andere.

- Wanneer homonimiese geskrifte (onder dieselfde naam) toegeskryf word aan die bekendste of beroemdste persoon met die betrokke naam, soos Johannes, Justinus, Klemens, Jakobus, ensovoorts.

- Die mees algemene motief was om geloofwaardigheid aan 'n geskrif te verleen deur dit in die naam van ' $n$ gesaghebbende geleerde te skrywe. Voorbeelde hiervan is onder andere die 132 pseudepigrafa onder Lusianus van Samosata se naam, die 900 homilieë onder die naam van Johannes Chrusostomos en die legio van godsdienstige en filosofiese traktate onder die name van mitiese figure soos Orfeus, Kubele en Hermes Trismegistos. In hierdie kategorie val ook die Aristeasbrief, die sogenaamde 3 Korintiërs en Laodiseabriewe van Paulus en volgens baie teoloë die Pastorale Briewe en Algemene Briewe. 


\section{3}

Die motiewe en dryfvere agter anonomiteit en pseudonimiteit kan nie alleen op grond van etiese, psigologiese en teologiese oorwegings verklaar en beoordeel word nie (Candlish 1981: 91vv, 26v). Dit is ' $n$ literêre konvensie wat op 'n ooreenkoms tussen letterkundiges berus (Laub 1980: 228v). Daarom moet onderskei word tussen pseudepigrafa wat geskryf is met die doelbewuste opset om te bedrieg of plagiaat te pleeg en, andersyds, egte pseudepigrafa wat bepaalde tradisies voortsit en uitbou (Metzger 1972: 4vv). In laasgenoemde geval word pseudepigrafie aangewend om die gedagtes van ' $n$ bepaalde skool of groep onder die name van die stigters of primêre eksponente van daardie skool uit te dra (soos Plato, Plurargus, Moses, Salomo, Paulus, Petrus, Johannes ensovoorts (Karavidopoulos 1977-78: 180vv). As sodanig identifiseer en weerspieël die latere geskrifte (pseudepigrafa) die tradisie van die skool (Zmijewski 1980: 100v).

\section{4}

Nuwe-Testamentiese pseudepigrafie is in 'n bepaalde opsig eiesoortig in soverre as wat dit saamhang met die fenomeen van apostolisiteit. Hierdie begrip het aanvanklik die gesag en geskrifte van die persone van die apostels aangedui. Dit was later die beskrywing van die verwantskap tussen Jesus se woorde en dade, sy dissipels en die apostels (sy gesante). Deur middel van pseudonimiteit word die vroeg-Christelike geskrifte dan met Jesus, die lewende Here en die ooggetuies van die Christus-gebeure geassosieer en dui pseudo-apostoliese outeurskap die verband met die aanvangsgebeure van die Christendom aan (Aland 1961: 4vv; Balz 1969: 410vv; Fischer 1977: 76v; Zmijewski 1979: 165vv; Laub 1980: 235v).

Hierdie toedrag van sake is teweeggebring toe apostolisiteit gedurende die tweede tot derde eeu al meer die konnotasie van historiese en leerstellige betroubaarheid verkry het. 'n Bestudering van die geskrifte van die apologete van die tweede tot die vierde eeue bevestig hierdie ontwikkeling, veral dié van Papias, Ireneüs, Origenes, Tertullianus en Eusebius (kyk o a Du Toit 1978: 165vv; Von Campenhausen 1968: 106vv, 194v; Blum 1963: 102vv).

\section{5}

Nuwe-Testamentiese pseudepigrafie openbaar terselfdertyd ook sekere 
van die algemene karaktertrekke van sy sekulêre eweknie, naamlik dat die klem by die beoordeling van hierdie literêre konvensie nie soseer op die persoon van die outeur gerig is nie, maar op die ware en suiwere inhoud van die geskrif in die bepaalde tradisie (kyk o a Speyer 1965/66: 119v, 123v; Fischer 1977: 77vv; Stenger 1976: 260v; Karavidopoulos 1977-78: 186v; Zmijewski 1980: 115v).

Hierdie oorweging geld besonderlik vir die aanvaarding, al dan nie, van die status en gesag van subapostoliese geskrifte van die Nuwe Testament.

\section{6}

Wat die Nuwe Testament betref, hou pseudonimiteit besondere implikasies in vir die vraag na die kanonisiteit van hierdie geskrifte. In hierdie verband word aandag geskenk aan verskillende genres van pseudepigrafa en die feit dat daar in subapostoliese gemeenskappe verandering in houding teenoor outeurskap ingetree het (kyk o a Aland 1961: 2vv). Dit hang saam met die bogenoemde verbreding van die begrip 'apostolisiteit' en die klemverskuiwing vanaf die persoon van die outeur na die inhoud van die geskrif. Die Hellenisties-Joodse milieu waarin die Nuwe Testament ontstaan het, het hier 'n rol gespeel tesame met die feit dat anonimiteit en pseudonimiteit by die skepping van geskrifte in die Nuwe-Testamentiese tyd hand aan hand gegaan het (kyk o a Paruzel 1975: 181vv).

\section{KONKLUSIE EN EVALUERING}

\section{1}

Die huidige stand van resultate van histories-kritiese navorsing oor outeurskap van Nuwe-Testamentiese geskrifte lei tot die standpunt dat verreweg die meeste Nuwe-Testamentiese geskrifte anonieme en/of pseudonieme geskrifte is.

Sedert Paulus sy egte briewe (d i Rom, 1 en 2 Kor, Gal, 1 Tess, Kol, Fil, Filem, (Ef)) geskryf het, is alle ander boeke anoniem of pseudoniem geskryf. Dit geld die vier evangelies, Handelinge, 2 Tessalonisense, Pastorale Briewe (onder Paulus se naam), Hebreërs, Algemene Briewe (1, 2, 3 Joh, Jak, 1 en 2 Pet, Jud) en Openbaring van Johannes (wat 'n pseudepigrafon is as aanvaar word dat dit in ongeveer $96 \mathrm{n} \mathrm{C}$ geskryf is 
en ten nouste met die apostel (vroeëre dissipel) Johannes verbind word).

\section{2}

Die feitelike toedrag is dus dat vanaf Paulus tot 1 Klemens (ong 96-100 $\mathrm{n} \mathrm{C)}$ alle vroeg-Christelike geskrifte ò anoniem ò pseudoniem geskryf is (kyk o a Fischer 1977: 76v). Hierdie gebruik is van die Joodse, Hellenistiese en Romeinse milieus geërf.

\section{3}

Die beoordeling en gevolglike legitimering of verwerping van hierdie konvensie vind basies plaas op die vlakke van egtheidskritiek en kopiereg wat 'n outeur op sy naam en geestesbesit (denke en standpunte) het. Bewyse hiervan is die feit dat Polikarpos tydens die stryd teen Marsion gewaarsku het teen laasgenoemde se vervalsing en verdraaiing van Paulus se briewe (Epistula ad Philippenses 3.2 en 7.1-2). Verder beroep Eusebius (HE 4.29.3-6) hom op Ireneüs in sy kritiek teen Tatianus wat lastering gepleeg het teen die vier evangelies (deur sy Diatessaron) en teen Paulus (deur sy parafrases en korreksies van Paulus se briewe).

In hierdie verband kan dus met stelligheid gekonstateer word dat sedert die vroegste tye twee vorme van pseudepigrafie deur almal verwerp is. Dit is plagiaat en pseudonimiteit met die doelbewuste opset om te vervals en lesers te bedrieg.

\section{4}

Dit beteken dat die vraag na die legitimiteit en aanvaarbaarheid van die literêre konvensie van veral pseudonimiteit slegs ten opsigte van 'n genuanseerde vorm van die gebruik geld. Dit gaan oor die vraag of daar binne die gees en situasie (milieu) van 'n bepaalde tradisie en literêre beweging die noodsaaklikheid bestaan om die tradisie op hierdie wyse oor te lewer en uit te bou.

K Aland (1961: 29v) handhaaf in hierdie verband die standpunt dat pseudepigrafie na vore getree het in die oorgang van die mondelinge na die geskrewe vorm van die Christelike tradisie oor Jesus se woorde en handelinge. Hierdie proses het onder leiding van die Heilige Gees plaasgevind. In so 'n benadering is die persoon van die outeur in feite 
onbelangrik en dien hy as werktuig slegs die doel om die oorspronklike tradisie op outentieke en betroubare wyse oor te lewer.

Die gebruik van die name van die apostels in die subapostoliese tyd dien dan as apostoliese legitimering van hulle betroubare weergawe van die tradisie. Die oorspronklike apostels was die enigste persone wat gesag en status gehad het om met en vir die vroeë algemene (ekumeniese) kerk te praat.

\section{5}

In die ontwikkelende situasie van die vroeë kerk vanaf die apostoliese na die sub-en post-apostoliese fases was apostolisiteit van geskrifte 'n waarborg vir betroubaarheid van die skriftelike oorlewering. Die ekumeniese kerk (Missionsgemeinde) het oorgegaan in die geïntitusionaliseerde plaaslike kerke (Frühkatholizismus) veral nadat geblyk het dat die paroesie langer uitgebly het as wat verwag was (Parusieverzögerung). Outentieke tradisies moes na hierdie plaaslike gemeentes oorgedra word. Dit is in die gees en gestalte van apostolisiteit deur medestanders van die apostels onder die name van apostels deur middel van pseudepigrafa gedoen. Hierdie pseudepigrafa het vir hulle die waarmerk van Jesus, die lewende Here, en van die oorspronklike apostels gedra.

\section{6}

Gedurende die tweede tot die vierde eeue het suiwerheid en betroubaarheid van oorlewering en noue verwantskap met die apostels des te meer belangrik geword as gevolg van die optrede van heterodokse groepe soos die Gnostici, Marsion en die Montaniste. Die stryd tussen die vroeë kerk en Judaïsme het ook nog tot diep in die tweede eeu voortgeduur (kyk die geskrifte van Paulus, Klemens, Justinus die Martelaar, Ignasius).

Dit blyk dus geregverdig te wees om te anvaar dat die omstandighede van die kerke, teologiese oorwegings en religieuse motivering die gebruike van anonimiteit (aanvanklik) en pseudonimiteit vir die vroeë kerk aanvaarbaar gemaak het.

In so 'n opset verskuif die klem vanaf die doelbewuste opset om die lesers te bedrieg en vanaf die beoefening van literêre tegnieke ter wille 
van literêre oorwegings as sodanig, na genuanseerde motiewe ontleen aan die gees, omstandighede en oortuigings van die Christelike tradisies. Die basiese motief was om die kerke met histories-betroubare en leerstellig-suiwere oorkondes van die lewende Jesus Christus en van sy apostels te bedien.

Tekenend hiervan is die mededeling in die Muratorianum (190-200 $\mathrm{n} \mathrm{C)}$ oor die ontstaan van die Johannesevangelie. Die skrywer deel ons mee dat die dissipel Johannes sy mede-dissipels (condiscipulis) en biskoppe (episcopis) bymekaargeroep het om saam met hom vir drie dae te vas om die suiwere openbaring te ontvang en dit saam te kontroleer ( $u$ t recognoscentibus cinctis).

\section{7}

Histories gesien het F Laub (1980: 228vv) dus gelyk as hy volhou dat Nuwe-Testamentiese pseudepigrafie as literêre tegniek nie slegs op grond van algemeen etiese, psigologiese en leerstellige gronde geëvalueer kan word nie. Die evaluering hang ten nouste saam met die feit en omstandighede van pseudo-apostoliese outeurskap in die tyd van die ontwikkelende en bedreigde post-apostoliese kerk. Hiermee hang ook saam die feit en implikasies van die anonimiteit van die vier evangelies, waarvan twee (Matteus en Johannes) van apostels is en twee (Markus en Lukas) van medestanders van apostels.

\section{8}

Die belangrikheid van 'n korrekte historiese perspektief op die feitelike situasie van die vroeë kerk is om metodologiese redes hier van belang. Op grond van wat in afdelings 1.1-1.6, vroeër in die studiestuk, uitgespel is, moet die implikasies hier deurgetrek word. Dit kom daarop neer dat dit illegitiem sou wees as 'n moderne navorser Nuwe-Testamentiese pseudepigrafie sou beoordeel slegs in terme van algemeen etiese en psigologiese norme wat op sekulêre literatuur van toepassing is. Moderne geleerdes mag ook nie hulle eie opvattings oor outeurskap van die Nuwe-Testamentiese geskrifte as uitgangspunt vir die vasstelling van die voorkoms van pseudepigrafa in die Nuwe Testament neem nie. Die oortuigings wat volgens primêre getuies destyds in die kerke self geleef het (afgesien daarvan of ons dit aanvaar of nie!), moet hier funksioneer. 
Die addisionele faktore wat hier in ag geneem moet word, is ten slotte die volgende:

\subsection{1}

Die reeds genoemde omstandighede waaronder die vroeg-Christelike tradisies geskep is (mondeling en geskrewe). Dit wil sê, die omstandighede waarin dit bewaar en oorgelewer is, en uiteindelik gelei het tot die ontstaan van die kanons van die kerke (eerste tot vierde eeu).

\section{8 .2}

Die motiewe waarom daar van pseudonimiteit gebruik gemaak is. Dit was naamlik om die oorspronlike mondelinge tradisie van Jesus Christus en die apostels op ' $n$ gesaghebbende en betroubare basis van 'n meer uitgebreide begrip van apostolisiteit te bewaar, oor te lewer en te interpreteer. Hierdie suiwerheid van apostoliese inhoud was die belangrikste kanonkriterium op grond waarvan geskrifte onder die name van apostels en hulle medestanders verwerp is (soos die Didache, Barnabasbrief, apokriewe evangelies, Handelinge, briewe en apokalipse).

\subsection{3}

Die oortuiging dat God deur Jesus Christus en die Heilige Gees die auctor primarius van die geskrifte was, het die persoon van die menslike outeur van minder belang gemaak. Die klem het dus meer-en-meer op die suiwere inhoud van 'n geskrif as op die persoon van die outeur geval.

\subsection{4}

Hierdie 'suiwerheid van inhoud' was vir die vroeë Christene die tradisie oor die woorde en dade van Jesus, die lewende Kúrios en die apostoliese getuienis hieromtrent. Die outeursvraag het dus gegaan oor die apostolisiteit van die geskrifte en nie oor die vraag of die geskrifte later pseudoniem onder 'n apostel se naam geskryf was nie.

\subsection{5}

Toe daar reeds in die eerste eeu valse apostels op die toneel verskyn het, (kyk o a 2 Kor 10-13) is hulle geïdentifiseer en afgewys. Hiermee 
saam is ook hulle lering en identifisering met die 'ware apostels' as vals en onaanvaarbaar afgewys (kyk o a 2 Tess $2: 2-4,15 ; 3: 17-18 ; 2$ Pet $1: 12-15 ; 3: 1 ; 2$ Tim 3:16; Jud 17-18).

\subsection{6}

Die vroeë kerk het vanaf die geskrifte van die 'apostoliese vaders' (Klemens, Barnabas, Didache, Ignasius, Polikarpos) tot by Eusebius van Sesarea (260-339 n C) die vier evangelies, Handelinge, 21 briewe en Johannesapokalips vir die kanon-in-wording oorweeg en dit beskou as geskrifte van die oorspronklike apostels en hulle medestanders (soos Markus en Lukas). Hierdie toedrag van sake word bevestig deur Justinus die Martelaar in ongeveer $160 \mathrm{n} \mathrm{C} \mathrm{(Dial} \mathrm{81)} \mathrm{en} \mathrm{die} \mathrm{Kanon} \mathrm{van}$ Muratori (190-200 n C) (kyk o a Du Toit 1978: 267vv).

\subsection{7}

Gedurende die derde tot vierde eeue het die apologete soos Origenes (in sy kommentaar op die Johannesevangelie en sy Homiliae), Tertullianus, Klemens Aleksandrinus (in sy Hipotiposes) en andere inderdaad aan valse outeursaanduidings aandag geskenk. Eusebius ( $H E$ 9.5.1 en 6.12.3-6) bespreek die standpunte van die apologete oor geskrifte onder Petrus se naam (soos 'n evangelie, brief en 'n apokalips), die Handelinge van Pilatus, ensovoorts.

'n Ondersoek van Eusebius se beskouing saam met die van Hiëronimus en die Konstitusies van die Apostels (veral 6.16), Sirillus van Jerusalem (veral Kategismus 4.36) bring aan die lig dat hierdie outeurs egtheidskritiek toegepas en vervalsings aan die kaak (probeer) gestel het (kyk o a Liechtenhan (1902: 222; Hulley 1944: 104v; Metzger 1972: 15). Ten opsigte van die 'omstrede boeke' (amfibálletai of antilegomena) word nie redes vir die twyfel of strydvrae verstrek nie. Dit geld die Algemene Briewe onder die name van Jakobus, Judas, 2 Petrus en 2 en 3 Johannes. Die omstredenheid van hierdie geskrifte word in elk geval nie in die Oosterse, Westerse en Siriese kerke aan hulle pseudonimiteit toegeskryf nie.

Eusebius (HE 3.1.1vv) stel dit dat Origenes skryf dat 2 Petrus nie as kanoniek (endiathēkon) ontvang is nie, maar wel as 'bruikbaar' (pareilefamen) bestudeer word. Hierby noem hy egter slegs dat 2 en 3 Johannes nie deur almal as 'eg' (ghnēsios) beskou is nie.

Die belangrikheid van hierdie karige inligting kry meer gewig as dit 
in verband gebring word met die derde groep geskrifte, naamlik notha ('onegtes' - Eusebius) of pseude ('onegtes' - Origenes). Hieronder val geskrifte soos die evangelies van Petrus, Tomas, Mattias, Egiptenaars, Basilides, die Handelinge van Andreas en van Johannes, die brief van Paulus aan die Laodisense en sy sogenaamde derde Korintebrief. Van hulle sê die Muratorianum onomwonde dat hulle vervals is onder apostels se name (Pauli nomine finctae) en fel enim cum melle misceri non congruit (dit pas nie om gal met heuning te vermeng nie). Eusebius ( $H E$ $3.25 .5 \mathrm{vv}$ ) beskou hierdie geskrifte as anaplasmata (hermodulerings, vervalsings) en hulle word afgemaak as atopa kai dusseb $\bar{e}$ (bose/onegte en onheilige boeke).

\subsection{8}

Die houding van die kerke ten opsigte van sommige pseudepigrafa word origens deur Eusebius (HE 6.12.3-6) beskryf. Hy deel ons mee dat teen die jaar $200 \mathrm{n} \mathrm{C}$ die evangelie en apokalips onder Petrus se naam na ' $n$ hewige kerkstryd onder leiding van biskop Serapion van Antiogië verwerp is. Die rede was dat dit as valse 'pseudepigrafa' op grond van on-apostoliese inhoud en spekulasies oor Jesus verwerplik is.

Tertullianus (De Baptismo 17.5) het ook 'n Asiatiese ouderling uit sy amp laat skors omdat hy 'n pseudonieme geskrif, Handelinge van Paulus en Tekla, 'uit liefde vir Paulus' geskryf het. Belangriker vir Tertullianus was egter dat die ouderling vir Paulus 'n on-Pauliniese teologie ten opsigte van die rol van die vrou in die erediens in die mond gelê het. Dat Tertullianus se prioriteite by apostoliese ortodoksie gelê het, word bevestig deur sy reël dat 'n geskrif van die leerling of medestander van 'n apostel (soos Markus van Petrus was) wesenlik as ' $n$ apostoliese geskrif beskou kan en moet word, ás die inhoud van die geskrif van apostoliese regsinnigheid getuig (Adversus Marcionem 6.5). Vir dieselfde rede is Teofilus van Antiogië se Epistula Apostolorum, 'n pseudepigrafon uit die tweede eeu, deur die kerk onder leiding van Ireneüs verwerp.

\subsection{9}

In korrekte historiese perspektief beskou, is die kerke se twyfel oor die gesag en aanvaarbaarheid van omstrede geskrifte dus nie hul pseudo- 
nimiteit of anonimiteit as sodanig nie, maar hulle on-apostoliese inhoud en hulle onbekendheid in die kerke. Die kwessie van pseudonimiteit (valse outeursaanduiding) wat wel ten opsigte van die notha en die evangelie en apokalips van Petrus ter sprake gekom het, is nie prominent ten opsigte van die omstrede boeke geopper nie (kyk verder by 5.8 .10$)$.

Daar kan gevolglik geen saak uitgemaak word vir die opvatting dat die vroeë kerk willens en wetens pseudepigrafa en vervalsings in hulle kanons opgeneem het nie. So 'n opvatting word weerspreek deur die getuienisse van die apostoliese vaders, Muratorianum, Origenes, Tertullianus, Eusebius en Hiëronimus.

Die standpunt (wat korrek mag wees) dat geskrifte soos die briewe van Jakobus, 2 Petrus, 2 en 3 Johannes en Judas, die Pastorale Briewe, en die Apokalips van Johannes pseudepigrafies van aard is, het nie vir die vroeë kerke gegeld nie en dateer eers uit die sestiende eeu, maar veral sedert histories-kritiese ondersoeke van JS Semler (1784) en daarna.

\section{8 .10}

Daar is hierbo aangedui dat 'n noukeurige ondersoek van die beskikbare primêre bronne uit die eerste drie-vier eeue uitwys dat daar in die Oosterse, Westerse en Siriese kerke stryd rondom die aanvaarding van die omstrede boeke was.

Hierdie boeke is Hebreërs (in Weste bestry), Openbaring (in Ooste lank bestry), 2 en 3 Johannes, 2 Petrus, Judas en Jakobus.

Die gedagte van pseudonimiteit kom egter slegs sporadies en op 'n lae profiel voor. Weer eens geld die feit dat die probleme met die omstrede boeke gesentreer het rondom die apostoliese kwaliteit van hulle inhoud en die historiese betroubaarheid van die geskrifte. Hierdie stryd om aanvaarding van die geskrifte is ook aangeblaas en gekompliseer deur die stryd teen veral Marsion en die Montaniste (kyk o a Du Toit 1978: 223-89).

'n Tekenende voorbeeld van die verloop van hierdie stryd rondom omstrede boeke is spekulasies in die eerste eeue rondom die Petrusbriewe. Eusebius (HE 3.3.1vv) skryf dat Origenes verklaar dat 2 Petrus nie as kanoniek ontvang is nie, hoewel dit bruikbaar voorgekom het (pareilefamen) en saam met die heilige skrifte bestudeer is. In sy Commentarii konstateer Origenes dat 1 Petrus ' $n$ erkende brief is (homologouménen), maar dat 'n tweede brief van Petrus betwyfel word (gar 
amfibálletai). Dieselfde twyfel geld ten opsigte van 2 en 3 Johannesbriewe wat Origenes nie as ' $\mathrm{eg}^{\prime}$ (ghnēsios) beskou nie (Eusebius HE 6.25.7-8).

Op 'n ander plek (Homilia oor Josua 7.1) skryf Origenes self dat Petrus luid geskal het deur middel van twee trompette, dit is sy twee briewe. Hierdie positiewe houding ten opsigte van albei Petrusbriewe word ook gehandhaaf deur Klemens van Aleksandrië wat in sy Hipotiposes kommentaar op al die algemene briewe lewer (Eusebius HE 6.14).

\subsubsection{1}

In die lig van hierdie ondersoek kan die volgende finale konklusie dus gemaak word.

Op grond van die oortuigings by die vroeë kerk en latere kerke dat die boeke wat in hulle kanons opgeneem is die waarmerk van apostolisiteit (geskryf deur die apostels en hulle medestanders) besit en primêr onder leiding van die Heilige Gees geskryf was, was anonimiteit en pseudonimiteit vir hulle geen probleem nie.

Gedurende die tweede tot derde eeue het daar 'n uitbreiding van die betekenis van 'apotolisiteit' plaasgevind, waardeur die klem nie op die persone van die apostels geval het nie, maar op die historiese betroubaarheid en leerstellige suiwerheid van inhoud van die getuienis aangaande die lewende Here Jesus Christus en die eerste apostels se oorlewering oor Hom. Hiervolgens kon iemand (soos Markus of Lukas) deur ' $n$ 'apostoliese' geskrif deelneem aan die oorlewering en interpretasie van die Jesus-tradisie, solank dit in ooreenstemming met die ortodoksie van die apostoliese tradisie geskied.

Hierdie opvatting en perspektief is verder ook moontlik gemaak binne die tradisionele tydsbegrip van die Hebreërs. Hulle het gewerk met die gedagte van die solidariteit van geslagte, oftewel 'n verenigde persoonlikheid (corporate personality). Dit beteken dat outeurs uit veel latere tye hulleself met vroeëre persoonlikhede en geslagte geidentifiseer en vereenselwig het - so asof die mense en geslagte dieselfde was.

'n Goeie voorbeeld hiervan is dat profete lank na die eksodus en ballingskap hulle tydgenote aangespreek het as mense wat God uit Egipte en Babilonië verlos het (kyk o a Rigt 6: 8v; Am 2: 10; Miga 6: 4; Hag 2: 5). Hierdie perspektief is deels ook verantwoordelik vir die pseudonimiteit van laat-Joodse apokaliptiese geskrifte èn van vroeg-Joodse apokaliptiek by Jesaja, Jeremia, Esegiël, Daniël, Sagaria en Joël.

Andersyds getuig die Nuwe-Testamentiese geskrifte self en die ge- 
skrifte van die apostoliese vaders en Apologete dat doelbewuste vervalsings ten opsigte van outeurskap en apostoliese inhoud deur almal sonder meer verwerp is.

Dit is insiggewend en van groot belang dat uitsprake teen valse apostels, valse leringe in woord en geskrif, valse profete en leraars juis voorkom in geskrifte wat vandag as pseudepigrafa beskou word, byvoorbeeld 2 Pet 1 : $12-15 ; 3: 1 ; 2$ Tess $2: 2,15 ; 2$ Tim $3: 14-17$.

Dus is dit 'n deeglik gesubstansieerde standpunt om te handhaaf dat anonimiteit ten opsigte van Nuwe-Testamentiese geskrifte 'n aanvaarde en selfs verkieslike tegniek was.

Wat pseudonimiteit betref, was dit aanvaarbaar en bruikbaar binne 'n breëre opvatting van apostolisiteit en in terme van eiesoortige teologiese en religieuse opvattings van die vroeë kerk tot in die derde eeu.

\section{Literatuurverwysings}

ABBOTT, FF 1908. Some spurious inscriptions and their authors. Classical Philology 3 , $22-30$.

ALAND, K 1961. Das Problem der Anonymität und Pseudonymität in der Christlichen Literatur der ersten beide Jahrhunderte. The Journal of Theological Studies 12, 39-49.

BALZ, HR 1969. Anonymität und Pseudepigraphie in Urchristentum. Zeitschrift für Theologie und Kirche 66, 4, 403-36.

BARDY, G 1936. Faux et fraudes littéraires dans l'antiquité chretienne. Revue d'histoire ecclésiastíque 32, 5-23; 275-302.

BENTLEY, R 1874. Dissertations upon the Epistles of Phalaris. Berlin: S Calvary.

BLUM, GC 1963. Begriff des Apostolischen im theologischen Denkens Tertullianus. Kerugma und Dogma 9, 102-21.

BRÖCKER, LO 1881. Die Methoden Galens in der literarischen Kritik. Rheinisches $\mathrm{Mu}$ seum 40, 415-38.

BROX, N 1973. Zum Problemstand in der Erforschung der altchristlichen Pseudepigraphie. Kairos 15, 1-2, 10-23.

BROX, N 1975. Zur pseudepigraphischen Rahmung des ersten Petrusbriefes. Biblische Zeitschrift 19, 1, 78-96.

BROX, N 1978. Tendenz und Pseudepigraphie im ersten Petrusbrief. Kairos 20, 2, 110-20.

BROX, N 1979. Methodenfragen der Pseudepigraphie-Forschung. Theologische Revue 75, $4,275-8$.

CANDLISH, JS 1981. On the moral character of pseudonomous books. Expositor 4, 4, $91-107 ; 262-79$.

CHAMBERS, EK 1891. The history and motives of literary forgeries. London: Longmans \& Green.

CLIFT, EH 1945. Latin Pseudepigrapha: A study in literary attributions. Baltimore.

COLLINS, JJ 1977. Pseudonymity, historical reviews and the centre of the Revelation of John. Catholic Biblical Quarterly 39, 3, 329-43.

DEUBNER, L (ed) 1937. De Vita Pythagorica. Leipzig: Teubner. (Sitaat is uit par 196, 108, $4-7)$.

FARRAR, JA 1907. Literary Forgeries. London: Longmans \& Green. 
FENTON, JC 1955. Pseudonymity in the New Testament. Theology 58, 51-63.

FISCHER, KM 1977. Anmerkungen zu Pseudepigraphie im Neuen Testament. New Testament Studies 23, 76-81.

GASQUE, WW \& MARTIN, RP (ed) 1970. Apostolic history and the Gospel: Essays presented to FF Bruce, 328-345. Exeter: Paternoster.

GOODSPEED, EJ 1931. Strange new Gospels. Chicago: CUP. [Uitgebreide uitgawe verskyn in 1956 onder die titel Modern Apocrypha (Boston: Beacon Press) en 'n herdruk in 1968 onder die titel Famous Biblical Hoaxes Grand Rapids: Baker Book House.]

GOODSPEED, EJ 1937. Pseudonymity and pseudepigraphy in early Christian literature. New chapters in New Testament study. London: A \& C Black.

GUDEMAN, A 1894. Literary frauds among Greeks. Classical studies in Honour of Henry Drisler, 52-74. New York: Macmillan.

GUTHRIE, D 1962. The development of the idea of canonical pseudepigrapha in New Testament criticism. Vox Evangelica 1, 43-59.

GUTHRIE, D 1970. Epistolary Pseudepigraphy. New Testament introduction, 671-684. 3rd Ed. London: Intervarsity Press.

HAEFFNER, AE 1934. A unique source for the study of ancient pseudonymity. Anglican Theological Review 16, 8-15.

HARRINGTON, W 1962. Irish Theological Quarterly 29, 23-4.

HARRISON, PN 1921. The problem of the Pastoral Epistles. London: OUP.

HECTOR, LC 1959. Paleography and forgery. London: St Anthony's Press.

HOSIUS, C 1913. Plagiatoren und Plagiatbegriff in Altertum. Neue Jahrbücher für das klassische Altertum 31, 176-93.

HULLEY, KH 1944. Principles of textual criticism known to St Jerome. Harvard Studies in classical Philology 55, 104-9.

KARAVIDOPOULOS, I 1977-78. To problema tes pseudepigrafias. Deltion Biblikon Meleton 5, 2-3, 178-88.

LAUB, F 1980. Falsche Verfasserangaben in neutestamentlichen Schriften. Aspekte der gegenwärtigen Diskussion um die neutestamentliche Pseudepigraphie. Trierer Theologische Zeitschrift 89/3, 228-42.

LIECHTENHAN, R 1902. Die pseudepigraphiphische Literatur der Gnostiker. Zeitschrift für die Neutestamentliche Wissenschaft 3, 222-37; 286-99.

MACDONALD, J \& HIGGINS, AJB 1971-72. The beginnings of christianity according to the Samaritans. New Testament Studies 18, 54-80.

MARQUART, J et al 1891. Galeni scripta minora 2, 91-124. Leipzig: Teubner.

METZGER, BM 1972. Literary forgeries and canonical pseudepigrapha. Journal of Biblical Literature 91/1, 3-24.

MEYER, A 1936. Religiöse Pseudepigraphie als ethischpsychologishes Problem. Zeitschrift für die Neutestamentliche Wissenschaft 35, 262-79.

PAGE, DL 1934. Actors' interpolations in Greek tragedy. Oxford: Clarendon Press

PARUZEL, H 1975. Autentikeco de la Nova Testamento. Biblia Revuo 11/4, 181-200.

PETER, H 1911. Wahrheit und Kunst, Geschichtsschreibung und Plagiat im klassischen Altertum. Leipzig: Teubner.

ROBERTS, JH \& DU TOIT, AB (red) 1978. Handleiding by die Nuwe Testament. Band 1. Pretoria: NG Kerk Boekhandel.

RONCONI, A 1956. Introduzione alla letteratura pseudoepigrafa. Studi classici e orientali $5,15-37$.

SINT, JA 1960. Pseudonymität im Altertum. Ihre Formen und ihre Gründe. Commentationes Aenipotanae 15, 25-67. Innsbruck: Universitätsverlag.

SPEYER, W 1965-66. Religiöse Pseudepigraphie und literarische Falschung in Altertum Jahrbuch für Antike und Christentum 8-9, 88-125. Münster: Aschendorffsche Verlagsbuchhandlung.

STEMPLINGER, E 1912. Das Plagiat in der griechischen Literatur. Leipzig: Teubner. 
STENGER, W 1974. Timotheus und Titus als literarische Gestalten. Kairos 16, 3-4, 252-67.

TAYLOR, A (et al) 1951. The bibliographical history of anonyma and pseudonyma. Chicago: CUP.

THESLEFF, H 1961. An introduction to the Pythagorean writings of the Hellenistic period. Abo: Akademi.

TORM, F 1932. Die Psychologie der Pseudonymitat im Hinblick auf die Literatur des Urchristentums. Studien der Luther-Akademie 2. Gütersloh: Bertelsmann.

TOUT, TF 1918-20. Mediaeval forgers and forgeries. Bulletin of the John Rylands Library 5, 208-34.

VON CAMPENHAUSEN, HF 1968. Die Entstehung der christliche Bibel. Tübingen: Mohr. (BhTh 39.)

WREDE, W 1900. Miscellen. Zeitschrift für die Neutestamentliche Wissenschaft 1, 75-86.

ZMIJEWSKI, J 1979. Apostolische Paradosis und Pseudepigrpahie im Neuen Testament. "Durch Erinnerung wachhalten". (2 Petr 1, 3; 3, 1). Biblische Zeitschrift 23/2, 161-71.

ZMIJEWSKI, J 1980. Die Pastoralbriefe als pseudepigraphische Schrifter-Beschreibung, Erklärung, Bewertung. Studien zum Neuen Testament und seiner Umwelt 4, 79-118. 